\title{
(Necessary and sufficient) Conditions for reforming pensions schemes in eastern Europe: Slovenia vs. Macedonia
}

\section{Introduction}

The road to democracy and a market-oriented economy was opened for eastern European countries right after the fall of the Berlin Wall in 1989, which symbolically marked the end of communism in all eastern European countries. Even though the direction towards a market-oriented economy was almost unquestionable, the way of achieving it was much more than an uncertainty.

One of the central policy questions of the transition economies of these countries was at what speed the policy reforms should proceed. The major debate was framed as a two-option solution: 'shock therapy' versus 'gradualism'. These two trends have been identified so far as distinguishing eastern European countries into two general groups. On the one hand rests those countries (such as Slovenia ${ }^{1}$ ) that have applied a more gradualist approach towards reforms; and, on the other, there are countries (like Macedonia) that have undergone more radical $^{2}$ changes. Such a trend in reform can be noticed also in connection with social policies where the most obvious, as well as the most disputable, example is the reform of the pensions system.

Privatisation of the pensions system has become, to quote Müller, the 'new pension orthodoxy':

Since 1998, several eastern European countries have opted for partial or full pension privatisation. (Müller, 2007: 162).

Even though the move to a multi-pillar system:

Clearly represents a new phenomenon in global approaches to old-age provision and is increasingly the norm in countries around the world, it is not fully accepted by all parties. (Orenstein, 2003: 172).

This is the case in eastern Europe where not all countries have implemented a full, radical privatisation of old-age schemes. Of particular importance at this point is to ask why some governments have privatised their existing public pay-as-you-go (PAYG) pension schemes while others have not.

1 In the early stages of its transition, Slovenia took a gradualist approach to reforms:

In the early period of transition, the main endeavour of economic policy was mainly to adjust to the new situation and only gradually to implement due reforms.

Cited from Human Development Report - Slovenia (1998): 78.

2 Radical, or 'shock therapy', reforms involved privatisation of their public sectors. 


\section{Theoretical framework and methodological approach}

\section{Theoretical framework}

To answer such a question, it is crucial first to expose the theoretical framework on which the analysis can be built. The existing theoretical literature on the political economy of pensions reform takes a path dependency approach, arguing that domestic reforms are constrained by already-existing political institutions and policy structures (Myles and Pierson, 2001). What the path-dependency approach suggests is that changes in the pensions system will only be marginal and very gradual. On the other side, Bonoli and Palier (2007) argue that single-pillar pensions systems do change and that the trend of this change embodies a shift towards a multi-pillarisation of the pension system.

However, if reforms are a reality, how is that possible? What are the conditions that lead to such a paradigmatic shift beside the path-dependency constraints? Many scholars (Deacon, Müller, Orenstein and Cerami) have identified the role played by international institutions as having been crucial in reforming eastern European pensions systems. However, we have to acknowledge - as Cerami warns us - that:

Transformation in central and eastern Europe has, in fact, not been simply the result of silent or semi-silent acceptance of prescriptions... but rather as a result of a recombinant policy implementation in which existing institutional structures have constrained and/or fostered the full completion of reforms. (2007: 4)

The suggestion given here to any researcher dealing with the causes of pensions reforms in the region is to make us aware that although:

International organizations have been important facilitators in the social policy reform process... this is still not sufficient to address them as the only causes responsible for specific outcomes. (Cerami, 2007: 4-5)

The influence of the international financial institutions (IFIs) in domestic policy processes alone does not appear to be a sufficient condition for multi-pillar pensions reform since, besides the pressure of the IFIs, some countries (Slovenia, for example) have not adopted full (privatised) multi-pillar reforms. The international pressure argument seems to be incomplete in explaining why eastern European countries have taken a 'different reform path', ${ }^{3}$ given that the pressure was the same. A different, but complementary, explanation that focuses on domestic political actors and context needs to be added here. In her work, Müller (2007) has suggested, besides the important role of the transnational and global policy actors (such as the World Bank and the International Monetary Fund), the importance of domestic political actors who are also agents of change in pensions reforms in eastern European countries.

Whatever the reasons are, it would seem important to investigate further the links between them. In order to have a full picture that can capture and explain all the cases,

3 Fultz (2004) speaks of 'two reform paths' taking place. On the one hand are those countries which are reducing public, pay-as-you-go systems in favour of funded schemes (Hungary, Poland, Bulgaria, Latvia, Estonia) while on the other hand are other central and eastern European countries (Czech Republic, Slovenia and Romania) who are adjusting their public retirement systems. 
it is crucial that interaction between these two conditions be investigated. The point being put forward here is that global pressure and the domestic political context did, as a consequence, influence the outcomes of pensions reforms. My hypothesis is that (first condition) the international actors were a necessary condition for pensions reforms in the eastern European region, but this alone is insufficient to explain why some countries have not undergone radical changes. In order to explain the different trends of these reforms - that is, the different responses to international pressures and the need for reform - we have to look at (second condition) domestic politics and actors as the final and definitive agents of change.

\section{Methodological approach}

In making my argument, I will focus my analyses on eastern European countries, acknowledging that:

Eastern factual context provides an excellent opportunity for testing existing theories. (Vanhuysse, 2001: 857)

To capture broadly the eastern European situation, this paper will compare the cases of Slovenia and Macedonia. These two countries from eastern Europe have had the same starting point, since before the reforms they were one country (former Yugoslavia) but they have had different outcomes concerning pensions reforms (the second-tier in Macedonia consists of a mandatory private scheme).$^{4}$ Identifying these two cases as having a most-similar background (the socio-economic situation) facilitates investigation on the conditions (the interaction between international and domestic actors) that have led to the most-different outcomes (the privatisation of the pensions system).

The analysis builds on the assumption that foreign influence, local actors and the policy context are the potential explanatory factors in pensions reform choices. ${ }^{5}$ Such an actor-centred approach towards understanding the conditions under which reforms were possible in the pensions system is not new (see, for example, Müller 2007; Fultz and Ruck, 2001) and, in the Eastern European context, the approach has proved to be a useful tool in explaining pensions reform. This paper, through factual awareness of the two cases, will try to bring the argument further in evaluating these factors either as necessary and/or as sufficient conditions.

Another methodological puzzle where assumptions need to be made concerns the classification of pensions schemes: which are the elements which must be identified? Most of the important works (for example, Bonoli, 2003; Myles and Pierson, 2001) providing a comparative evaluation of pensions reform trajectories have based their analysis on the old distinction between Bismarckian and Beveridgean systems. However, such a classification of countries holds methodological shortcomings since, as it has been argued, it is:

4 See table in the Appendix.

5 Müller speaks of foreign influence, local actors and the policy context as explanatory factors for pensions reform choices. 
An extremely broad divide which centres on the major differences across pension regimes ... [and which is]... not specific enough to grasp the impact of the pension reforms adopted throughout Europe. (Arza, 2006: 2).

What's more, the Bismarckian-Beveridgean divide is problematic especially when dealing with eastern European countries. This is not only because of the pre-1991 'existing Bismarckian traditions in eastern Europe' (Müller, 2002: 295) but because of the actual situation in which you find elements of both models simultaneously embedded in a country's pensions system (for example Slovenia ${ }^{6}$ ). To cite Cerami:

The welfare regime in Central and Eastern Europe can, therefore, be described in terms of a recombinant welfare state, where Bismarck features remain preponderant (2007: 3).

Other alternative classifications are based on the different 'pillars' contained in a system (the World Bank uses the 'three pillar' terminology, whereas the ILO uses the 'three-tier' pensions system). Here, it needs to be stressed that different uses are made of the term 'pillar' (Yermo, 2002). To escape such shortcomings, the multi-pillar approach should be read in this article as embodying the sense proposed by the World Bank. ${ }^{7}$ Adopting such an approach, one needs to look at whether a country is a singlepillar system or a multi-pillar system putting the emphasis on the existence or otherwise of a mandatory funded pillar. This is because:

(Pension) privatization is what has been considered the major paradigm shift in the region's old-age security arrangements. (Müller, 2002: 155)

\section{Common challenges, different approaches}

Slovenia and Macedonia were part of the Yugoslav federation:

With an economic system founded on social ownership of the means of production, and high degrees of both redistribution and domestic protection. ${ }^{8}$

They come from a very similar socio-political background (being part of the same state) but they took different paths during the transition to the market economy. The social policy picture of these two countries, right after independence, became diverse. It has been argued that:

Slovenia is developing into a variant of a West European welfare state, combining a mix of Bismarckian-style insurance and Scandinavian-style state financing; while Macedonia appeared to be attempting to conserve state and workplace benefits in the face of declining resources, possibly leading to imminent collapse of the old welfare system and the subsequent residualization of social policy. (Deacon, 2000: 151; Manning, 2004: 219).

6 See the table in the Appendix.

7 'Multi-pillar reform (system): Pension reform (system) with a first pillar that is public (generally PAYG); a second pillar that is mandatory and funded; and a third pillar that is voluntary and funded'. Cited by World Bank, 2006: xxiii.

8 Human Development Report: Slovenia 1998: 77. 
Trying to employ the Bismarckian vs. Beveridgean type of classification seems useless in categorising these countries since, for example, the:

Macedonian pension system is much more of a hybrid with PAYG scheme where only the employer is paying the contribution for his employees for an old-age or disability pension and at the same time there is a legal frame for some additional pension schemes based on the capital funded model. (Xhumari-Vaso, 2003: 6)

\section{Common challenges...}

The overall accepted view has been:

That the old-age security systems inherited from the socialist past were in dire need of reform, to secure their financial sustainability, to meet the demographic challenges ahead and to adapt some of the previous design features to the new economic order. (Müller, 2007: 5)

The first challenge widely presented in the literature is due to the demographic shift (population ageing). Both countries have a population of two million people but Macedonia is regarded as a 'young country', with 30\% of the population being under $20,{ }^{9}$ while Slovenia already has one of the worst demographic profiles in Europe. ${ }^{10}$ This dramatic demographic picture is projected to worsen although, between 2000 and 2050, Slovenia will still be the worst in Europe..$^{11}$ But estimations do not predict a better situation even for Macedonia where, by 2020, the elderly will have increased by over $70 \%$, from roughly $13 \%$ to $23 \%$ of the population, in just twenty years. ${ }^{12}$

What is even more interesting here is to see the dependency ratio of these countries; during the 90s, the number of pensioners as a percentage of the number of workers was almost the same in both countries. In the pre-1992 period, this figure was around $30 \%$, followed by a similar increase in subsequent years..$^{13}$ By 2000 , however, the total dependency ratio in these countries was different by seven whole percentage points (Slovenia 42.4\% and Macedonia 49.4\% - see Fultz and Ruck, 2001: 22). The latest projections undertaken by the World Bank demonstrate that both Macedonia and Slovenia face even larger increases to their already high old-age dependency ratios (World Bank, 2007: 16).

This high dependency rate is reflected in the high pensions expenditures of these countries. In 1997, 30\% of the expenditure of the Macedonian government was taken up by pensions, which make pensions expenditure in Macedonia among the highest in the region (CRPM, 2005a). In Slovenia, pensions expenditure as a percentage of GDP was low in the 90 s, almost less than $10 \%,{ }^{14}$ but, in 2007, it had increased up to $19 \%$ with a projection that, by 2050 , it will have reached $28 \%$ of GDP..$^{15}$

9 CRPM, 2006: 11.

10 EPN (European Pensions \& Investment News) 7 June 2004 http://www.epn-magazine.com/news/fullstory.php/aid/868/In_brief.html

11 World Bank, 2005: 14.

12 q.v. CRPM, 2006: 11; and Fultz and Ruck, 2001: 9.

13 'Pensioners as a per cent of workers in selected CEE countries in two years'; Figure 4 in Fultz and Ruck, 2001: 8.

14 Chart 1 in World Bank, 2005: 4. 
A situation where the dependency rate is rising and where pensions expenditure will rise relative to the revenue is argued likely to cause substantial fiscal problems. Many scholars look at the demographic shift (an indirect factor, since it influences the dependency rate) and the dependency ratio as factors that have negative implications for the financing of PAYGs, but there are others who argue that:

The crucial factors may be changes in more general patterns of employment [such that] the future of the pension system seems to be in the hands of the labour market. ${ }^{16}$

Following such logic and looking at employment data for the 1991-1998 period, it can be observed that there has been a loss of employment in both countries, although this was higher in Macedonia than in Slovenia. Contribution rates in Slovenia stood for some time at the same rate but, after 1996 it was reduced twice in order to lower labour costs (Novak: 280). It has been noted that this reduction in employment has had negative effects since:

Contributions falling and benefit payments increasing will create a widening financial gap. Fultz and Ruck (2001: 5)

Such a situation was critical and unaffordable by the two countries, so the only solution was the reform of the pensions system. This is not something new since most eastern European countries have undertaken major pensions reforms but the question is what kind of reforms have been undertaken. Did these countries' reform programmes entail a shift toward a greater reliance on the private sector for pensions provision? That is, was privatisation the outcome of their reforms?

\section{... but different approaches}

The World Bank (in 1996), in an assessment of 28 countries, found that reforms in the social-policy field for both Slovenia and Macedonia have been both substantial and well-advanced, ranking them among those countries (Poland, Hungary, Croatia, Slovak Republic and Czech Republic) which had undergone the most reform. ${ }^{17}$ However, even though reforms took place in those countries, they belong to two different trends as suggested by the literature (see Fultz, 2004). Macedonia takes its place in the first group of countries that were:

... scaling down public, pay-as-you-go schemes and putting in place along side them commercially managed individual savings schemes,

while Slovenia belongs among the second group of countries that were:

15 The IMF pointed out in a report on a mission in Slovenia that in less than 10 years, more than half of voters will be retirees; under current policies, the demographic pressures are expected to increase age-related expenditures from 19\% of GDP presently to almost $28 \%$ by 2050 .' Ottawa, 2007.

16 Augusztinovics (1999), p. 96, cited from Fultz and Ruck, 2001: 22.

17 q.v. Manning, 2004: 219; and Deacon, 2000: 150. 
Combining adjustments in their public pension systems with the development of voluntary supplemental retirement schemes. (Fultz, 2004: 16; and Laviec and Fultz, 2000: 7)

Macedonia has already implemented full multi-pillar reform, establishing thereby a new pensions insurance system consisting of three pillars. The first pillar consists of compulsory pensions insurance based on the pay-as-you-go model, maintaining a defined benefit (DB) formula. In a supplement to the already-existing PAYG pensions system, mandatory fully-funded pensions insurance was adopted in April 2002 as a second pillar. The introduction of this compulsory capital-funded pension shall take up $7 \%$ of the total $20 \%$ that are paid as contributions for pensions and disability insurance (Holzmann and Hinz 2005: 152; and MAPAS ${ }^{18}$ ) and is:

Part of the compulsory scheme for individuals employed for the first time after January 1 , 2003. (Xhumari-Vaso, 2003: 4)

A voluntary, fully-funded pensions insurance scheme also exists for contributors employed before 2003.

In Slovenia, a new multi-pillar pension system was proposed but only the first mandatory and the third pillar was legislated, with the proposed second pillar being rejected. ${ }^{19}$

In Macedonia, the current reform of the pensions system was structural, accompanied by the introduction of mandatory private pension funds, whereas in Slovenia only parametric reforms were targeted in which:

Two major legislative efforts to fix the PAYG system stand out - the Pension and Disability Insurance Acts of 1992 and 1999. (Müller, 2002: 298)

Such parametric reforms raised the retirement age. For men, this was increased from 61 to 63 for full retirement with a 40-year qualifying period, while for women the full retirement age was gradually increased from 58 to 61 (and by 2008 will reach 63 ), with a 38-year qualifying period; for both, the minimum retirement age is 58 (Fultz and Ruck, 2001: 13). In Macedonia, men will acquire the right to the first pillar old-age pension scheme at the age of 64 , while women can retire at the age of 62, both after having accomplished 15 years of work; ${ }^{20}$ or, if they have completed a working period of 40 years (men) and 35 years (women), regardless of their age (XhumariVaso, 2003: 4).

The socio-economic situation of both countries pronounced challenges to the basic structure of their pensions system, but the response which was found was different. The Slovene and Macedonian pensions reforms took different paths for the same challenges. The main distinguishing element is the privatisation (mandatory) of the second pillar - but why? What were the conditions that brought such different choices?

18 MAPAS (Agency for the Supervision of Fully-Funded Pensions Insurance).

19 In December 1999, the Slovenian Parliament deleted a proposal for a new mandatory savings scheme for all private sector workers from a comprehensive pensions reform bill, while approving those provisions which strengthened the financing of the existing public scheme (Fultz and Ruck, 2001: 18). ibid. p. 13. 


\section{Conditions for reforming pension schemes}

Between foreign influences...

\section{The role of international organisations}

Müller (1999: 55) reminds us that, within a more paradigmatic perspective, the controversies are between Anglo-American liberalism and the continental European welfare state tradition. Such divergences on how to reform pensions systems, she goes on to argue, rest on the most prominent international organisations. On the one side, there are the World Bank and the IMF (the international financial institutions) promoting a model which is more market-oriented. And, on the other side, there is the International Labour Organisation, which has a more social character. The famous World Bank report 'Averting the Old Age Crisis' holds the (normative) assumption that the privatisation of the pensions scheme (mandatory funded schemes) is inherently superior to (PAYG) public ones. ${ }^{21}$ Contrary to these claims, ILO representatives:

... have tried to refute this assessment: in their opinion, many of the existing public PAYG systems continue to function efficiently, without being at the brink of collapse, and, once reformed, will be able to face the demographic challenge. ${ }^{22}$

In a more recent study looking at the trends in pensions reform and implementation in EU accession countries, in responding to the World Bank's 1994 report, the ILO argues that:

The shift from pay-as-you-go to advance funding does not avert the challenge of ageing. (Fultz, 2003: 19)

Besides such a divergence of views, it needs to be stressed that the pillarisation of the pensions system has been seriously considered across all eastern European transition states, not excluding even:

Slovenia, which has been considering a three-pillar system for several years. (Charlton et al, 1998: 1425)

Undoubtedly the main actors that have pushed these countries (Slovenia included) towards multi-pillar-type reform has been the IMF and the World Bank - the 'radical agenda shifting'23 (Müller, 2002: 295) actors. The mechanism through which these global institutions have pushed these countries toward pillarisation is questionable in the literature. Some scholars maintain that, through conditionality ${ }^{24}$ the IFIs use their financial leverage to compel governments to adopt their policies while others have found little empirical evidence to support this view (Brooks, forthcoming: 74-75).

21 Müller, 1999: 56.

22 Cichon, 1995 (referenced from Müller, 1999).

23 'Radical agenda shifting in old-age security reform was frequently connected to World Bank involvement.' (Müller, 2002: 295)

24 'Studies that emphasise the power of loan conditionality typically assume that loans are offered with the condition that, if a recipient country does not implement a specific model, the support will be withdrawn.' (Brooks, forthcoming: 74-75). 
The conditionality argument remains poorly understood, but it is true that back-up support has favoured those countries undergoing market-oriented pensions reforms. The World Bank loan given to Macedonia is more than three times higher compared to what has been given to Slovenia ${ }^{25}$ (notice here that their population is the same size). Here, we have to acknowledge that:

The switch from PAYG to fully-funded financing implies high transition costs since a double burden is placed on the transitional generations that have to contribute to their own retirement plans, while also paying for current pension obligations. (Müller, 1999: 56)

So, the vast financial and technical resources held by the IFIs do give them an important degree of influence on the decision-making process of government policymakers (Brooks, forthcoming: 76).

\section{EU 'indifference'vs. World Bank 'hegemony'26}

Where the overall pressure of the IFIs has been evident is in the direction and support for transition countries towards market-oriented reforms, which has left these countries lacking in incentives towards social-oriented reforms. A legitimate question here may be what role has been played by the EU in the overall transformations of policies in these countries since they all opted for joining the EU.

In the literature, it has been argued that:

At the level of rhetoric, the EU in general, and DG5 in particular, exhorts the countries of the region to establish a social dimension to their market economies... [but] in practice many authors have observed that there has been very limited influence from the EU on social policy. (Deacon and Stubbs, 2003: 7)

The problem of EU inefficiency in influencing the social policies of the then preaccession countries relates for the most part to the little social policy orientation held by the most significant financial instrument (the PHARE programmes): only $3.6 \%$ of the total PHARE budget was used for social development and employment (Lendvai, 2004: 4). If even that little financial support was allocated to the social policies of countries in the pre-accession phase (including among them Slovenia), in the case of other south-eastern Europe (western Balkans) countries, financial support for policy change was almost neglected since western Balkans countries were facing other problems (such as ethnic conflicts and poverty issues). So, in Macedonia the PHARE programme was nothing but financial assistance for crisis recovery. In this way, the EU and models of a social Europe were absent from the centre stage in most of the key debates and technical assistance programmes regarding social policy in south-eastern Europe (Deacon and Stubbs, 2003: 8).

From the above analysis, it can be clearly shown that the region was caught between the 'indifference' of the EU and the hegemony of the World Bank. The European Union did not deliver any concrete model for a pensions scheme... leaving the

25 Amount of loans to Macedonia: \$26.2m (Table B2, p. 66); amount of loans to Slovenia: $\$ 7.7 \mathrm{~m}$ (Table B4, p. 67). (World Bank, 2006).

26 Terms used by Deacon and Stubbs, 2003. 
ground free for other influences, mainly those coming from the World Bank and the IMF (CRPM, 2005b: 4). The EU was weak in shaping these countries' pensions policies and the only pressures were those coming from the IFIs. Given this influential pressure from the IFIs, one would expect that both countries would follow the same model of reforms, i.e. that of privatisation. But that was not the case, since these countries took different paths.

Seen from this perspective, the arguments over international pressure can be seen as providing just the background condition for change, telling us nothing about what directions those reforms took. The IFI actors provided the necessary conditions to push these countries towards reform, but these alone are not sufficient to explain why different countries undertook different kinds of reforms. This is why we need to search for other conditions that can explain such divergences.

\section{... and the domestic response}

In the literature, it has been convincingly argued that, whereas the privatisation of old-age security was clearly a major policy recommendation from abroad facing any pensions reformer in eastern Europe,

It was the domestic political process that eventually resulted in the adoption or rejection of radical pension reform. (Müller, 2002: 295)

Such propositions, where the:

Local factors' influence on developing reforms... differ significantly from one country to another, (Fultz and Ruck, 2001: 11)

have been reaffirmed also by empirical analysis (see Brooks, 2005), which finds that domestic political institutions play an important role in explaining where private pension models are adopted.

Our cases of analysis, Slovenia and Macedonia, take the argument further by highlighting the importance of domestic actors as being the sufficient condition in an explanation of why there is such a divergence in the pattern of reform. The interesting thing is to look at how they have managed (or not) to handle the reform pressure placed by the IFIs.

Slovenes, unlike domestic actors in the rest of the countries of south-eastern Europe, have not followed IMF policies; instead, Slovenia was able to press the point to the IMF that it was not coming out of the same system as the other [former] socialist countries (Stavrova, 2006: 5). The IMF, in its most recent report on future pensions in Slovenia, threatens the country with the urgency of reform, but the authorities continue to argue that systemic changes to pensions provision are not possible (Ottawa, 2007). If Slovenia scores well in backing away from IFI pressure, the contrary is noticed in the case of Macedonia, which felt weak in handling the pressures for radical reforms.

One of the reasons why some countries can resist such international pressure whereas others can not depends, it has been argued, on the external debt held by those countries: when external debt is high, governments tend to stress their general commitment to market-oriented reforms (Müller, 2002: 296). It can be seen from World Bank reports that Slovenia has a low level of external debt. ${ }^{27}$ Such relatively low levels of 
external debt have rendered Slovenia less open to the influence of the international financial organisations and their favouring of privatisation strategies (Ottawa, 2007).

Another factor, also widely recognised in the literature, is the role of the trade unions. A study by the International Labour Organisation (ILO) has found that the Slovene government's posture has been influenced by strong opposition from trade unions who perceive pensions privatisation as undermining the public social insurance system (Fultz, 2004: 17).

Lastly, it needs also to be mentioned that Slovenia has shown a strong orientation towards the continental European mainstream. Government officials explain the refusal of the privatisation of the pension reforms (proposed in 1999) as:

Reflecting views widely held in Slovenia that the proposed privatization was not consistent... with Western European pension schemes. (Fultz and Ruck, 2001: 18)

\section{Concluding remarks}

Reforms in the pensions system have been the norm for the eastern European region, but it is observed that countries are moving on different paths. What this article has tried to discuss is the source of this variation in explaining why such different trends have been possible. In analysing the conditions that have brought the reforms, it has observed that the responses of eastern European countries towards the IFIs have been different even though the pressures have been the same. Such findings confirm that, whereas the privatisation of old-age security was clearly a major policy recommendation, and backed up by the IFIs, the kind of reform that was applied was chosen by domestic political actors who determined whether to adopt or reject radical pensions reform. My argument is that the pressures of the international financial organisations constitute only a necessary condition for expecting domestic changes (reforms) in pensions schemes. The response to these changes - that is, the direction and the degree or type of these reforms - is sufficiently determined by domestic actors and their positions. Whether such reforms lead to a more radical paradigmatic shift depends on the preferences of the domestic actors and their strategies and orientations.

Extending the analysis further, this paper suggests that it is most interesting if the explanatory factors for pensions reform choices in eastern Europe are approached as necessary and/or sufficient conditions. Following the logic of such an argumentation, it can be concluded that it is the domestic political actors who are the decisive actors (the sufficient condition) for the types of reforms in pensions scheme made in response to the level and application of global influence (the necessary condition).

\section{References}

Adam, Jan (2001) Book Review (Katharina Müller The Political Economy of Pension Reform in Central-Eastern Europe) Journal of Comparative Economics 29(3): 579-580.

Bonoli, Giuliano (2000) 'Two Worlds of Pension Reform in Western Europe' Comparative Politics 35(4): 399-415. 
Bonoli, Giuliano and Bruno Palier (2007) 'Comparing Old Age Insurance Reforms in Bismarckian Welfare Systems’ Comparative Social Policy Analysis.

Brooks, Sarah (2005) 'Interdependent and Domestic Foundations of Policy Change: The Diffusion of Pension Privatization Around the World' International Studies Quarterly 49: 273-294.

Brooks, Sarah (forthcoming) 'What was the Role of International Financial Institutions in the Diffusion of Social Security Reform in Latin America?' in Kurt Weyland (ed.) Learning from Foreign Models in Latin American Policy Reform Washington, DC: Woodrow Wilson Center Press; and Johns Hopkins University Press.

Camila, Arza (2006) Welfare regimes and distributional principles: A conceptual and empirical evaluation of pension reform in Europe Working Papers 2006/30, IUE http://www.iue.it/RSCAS/WP-Texts/06 30.pdf

Cerami, Alfio (2007) 'The Politics of Reforms in Bismarckian Welfare Systems: The Cases of Czech Republic, Hungary, Poland and Slovakia' paper presented at the conference The Europeanization of the reforms of welfare systems Connex workshop/Espanet Expert seminar, 8-10 March, CEVIPOL: Paris.

Charlton, Roger, Roddy McKinnon and Lukasz Konopielko (1998) 'Pensions Reform, Privatisation and Restructuring in the Transition: Unfinished Business or Inappropriate Agendas?' Europe-Asia Studies 50(8): 1413-1446.

CRPM (Centre for Research and Policy Making) (2005a) Pension System Reform in Macedonia Occasional Paper No. 7, September.

http://www.crpm.org.mk/Papers/Pension.htm

CRPM (Centre for Research and Policy Making) (2005b) Models of pension schemes promoted by international organisations Occasional Paper No. 6, August, Skopje.

CRPM (Centre for Research and Policy Making) (2006) Public Management Reform: Modernizing Pension Systems in Sweden and Macedonia Policy Study No. 2, Skopje.

Deacon, Bob (2000) 'Eastern European welfare states: the impact of the politics of globalization’ Journal of European Social Policy 10(2): 146-161.

Deacon, Bob and Paul Stubbs (2003) 'The Making of Social Policy in South-Eastern Europe: Theories, Methods, Politics' paper presented at GASPP 6 Seminar Thessaloniki, Greece, 19-20 September: Globalisation, Regionalisation and the Making of Social Policy in South-Eastern Europe.

Fultz, Elaine (ed.) (2002) Restructuring of Public Pension Schemes: Case Studies of the Czech Republic and Slovenia (Pension Reform in Central and Eastern Europe, Volume 2) International Labour Organization.

Fultz, Elaine (2003) Recent trends in pension reform and implementation in the EU accession countries Budapest: International Labour Office http://www.ilo.org/ public/english/region/eurpro/budapest/download/pension_trends.pdf

Fultz, Elaine (2004) 'Pension reform in the EU accession countries: Challenges, achievements and pitfalls' International Social Security Review 57(2): 3-24.

Fultz, Elaine and Markus Ruck (2001) Pension reform in central and eastern Europe: An update on the restructuring of national pension schemes in selected countries ILO CEET Policy Paper No. 25, Budapest: International Labour Office. 
Holzmann, Robert and Richard Hinz (2005) Old-Age Income Support in the 21st Century: An International Perspective on Pension Systems and Reform No. 2, May, World Bank: Washington, D.C.

HDR (Human Development Report: Slovenia) (1998) 'Slovenia in Time and Space' Chapter 6 in Jana Javornik and Valerija Korošec (eds.) Human Development Report - Slovenia. http://www.gov.si/umar/aprojekt/hdr/98/human6.pdf

IEG (Independent Evaluation Group) (2006) Pension Reforms and the Development of Pension Systems: An Evaluation of World Bank Assistance World Bank: Washington, D.C. http://www.worldbank.org/ieg/pensions/

Kupiszewski, Marek, Jakub Bijak and Beata Nowok (2006) Impact of Future Demographic Changes in Europe CEFMR Working Paper 6.

Laviec, Jean-Pierre and Elaine Fultz (2000) 'Foreword' in Elaine Fultz (ed.) Restructuring of Public Pension Schemes: Case Studies of the Czech Republic and Slovenia (Pension Reform in Central and Eastern Europe, Volume 2) International Labour Organization.

Lendvai, Noémi (2004) 'The weakest link? EU Accession and Enlargement: dialoguing EU and post-communist social policy' Journal of European Social Policy 14(3). Special issue on 'EU Accession, Europeanisation and Social Policy', edited by Ana Guillen and Bruno Palier.

Müller, Katharina (1999) 'Pension Reform Paths in Comparison: The Case of Central-Eastern Europe' Czech Sociological Review 7(1): 51-66.

Müller, Katharina (2002) 'Beyond privatization: pension reform in the Czech Republic and Slovenia' Journal of European Social Policy 12: 293.

Müller, Katharina (2007) 'The politics and outcomes of three-pillar pension reforms in Central and Eastern Europe' in C. Arza and M. Kohli (eds.) The Political Economy of Pension Reform: Politics, Policy Models and Outcomes in Europe London: Routledge.

Myles, John and Paul Pierson (2001) 'The Comparative Political Economy of Pension Reform' in Paul Pierson (ed.) The new politics of the welfare state Oxford: Oxford University Press, pp. 305-333.

Novak, Ales 'Pension system reform in Slovenia' Europe-Asia Studies 56(2): 279-292.

Orenstein, Mitchell (2003) 'Mapping the Diffusion of Pension Innovation' in R. Holzmann, M. Orenstein and M. Rutkowski (eds.) Pension Reform in Europe: Process and Progress World Bank: Washington, DC.

Ottawa, Barbara (2007) Slovenia hears IMF age warning but cannot act IPE.com, 29 May. http://www.ipe.com/news/Slovenia hears IMF age warning but cannot act 22159.php?type $=$ news\&id $=22159$

Rutkowski, Michal (1999) 'The Quest for Modern Solutions: Pension Reforms in Transition Economies' presentation for the conference Ten Years After: Transition and Growth in Post-Communist Countries Warsaw: Poland, 15-16 October http://coin.wne.uw.edu.pl/liberda/additional materials/liberda/pan pension2.html

Stavroda, Biljana (2006) 'The Western Balkans: A Decisive Year for Integration' in Transitions Online 2 March. 
Vanhuysse, Pieter (2001) 'The Political Economy of Pensions: Western Theories, Eastern Facts' in Christiansen and Thomas (eds.) 'Review section' Journal of European Public Policy 8(5): 853-861.

World Bank (2005) 'Special Topic: Sustainability of Pension Systems in EU8' World Bank EU8 Quarterly Economic Report October.

World Bank (2006) Pension Reform and the Development of Pension Systems: An Evaluation of World Bank Assistance World Bank: Washington, D.C.

World Bank (2007) From Red to Gray: The 'Third Transition' of Aging Populations in Eastern Europe and the Former Soviet Union World Bank: Washington, D.C.

Xhumari-Vaso, Merita (2003) 'A comparative analysis of old-age pension schemes in Albania, Kosovo and Macedonia' paper presented at the 4th International Research Conference on Social Security: Social security in a long life society Antwerp, 5-7 May.

Yermo, Juan (2002) 'Revised Taxonomy for Pension Plans, Pension Funds and Pension Entities' OECD. http://www.oecd.org/dataoecd/34/23/2488707.pdf

\section{Appendix}

\begin{tabular}{|c|c|c|c|c|c|}
\hline \multicolumn{3}{|c|}{ Characteristics } & Macedonia & Slovenia & Reference \\
\hline \multicolumn{3}{|c|}{ Social system } & $\begin{array}{l}\text { Conserve state and } \\
\text { workplace benefits }\end{array}$ & $\begin{array}{l}\text { West European } \\
\text { welfare state-style }\end{array}$ & $\begin{array}{l}\text { Deacon, } \\
2000\end{array}$ \\
\hline \multicolumn{3}{|l|}{ Reforms } & Yes & Yes & \\
\hline \multicolumn{3}{|l|}{ Pillars } & Three-pillar & Two-pillar & \\
\hline \multirow[t]{3}{*}{$\begin{array}{l}\text { Status of } \\
\text { pension } \\
\text { reform: }\end{array}$} & \multicolumn{2}{|c|}{$\begin{array}{l}\text { Major } 1^{\text {st }} \text { tier of } \\
\text { reform (mandatory) }\end{array}$} & $\begin{array}{l}\text { Legislated } \\
\text { maintained PAYGs; } \\
\text { defined benefit (DB) }\end{array}$ & $\begin{array}{l}\text { Legislated } \\
\text { maintained PAYGs; } \\
\text { defined benefit (DB) }\end{array}$ & $\begin{array}{l}\text { Fultz and } \\
\text { Ruck, } \\
2001: 11\end{array}$ \\
\hline & \multicolumn{2}{|c|}{$\begin{array}{l}\text { Introduction of } \\
\text { mandatory } 2^{\text {nd }} \text { tier }\end{array}$} & Legislated & Rejected & \\
\hline & \multicolumn{2}{|c|}{$\begin{array}{l}\text { Additional voluntary } \\
\text { arrangement }\end{array}$} & Legislated & Legislated & \\
\hline \multirow{2}{*}{\multicolumn{2}{|c|}{ Retirement age }} & Men & $\begin{array}{l}64 \text { with } 15 \text { years of } \\
\text { work }\end{array}$ & $\begin{array}{l}63 \text { with } 40 \text {-year } \\
\text { qualifying period; } \\
\text { minimum retirement } \\
\text { age } 58 .\end{array}$ & $\begin{array}{l}\text { Fultz and } \\
\text { Ruck, } \\
2001: 13\end{array}$ \\
\hline & & Women & $\begin{array}{l}62 \text { with } 15 \text { years of } \\
\text { work }\end{array}$ & $\begin{array}{l}61 \text { with } 38 \text {-year } \\
\text { qualifying period; } \\
\text { minimum retirement } \\
\text { age } 58 .\end{array}$ & \\
\hline \multicolumn{3}{|c|}{$\begin{array}{l}\text { Total dependency ratio }(\%) \\
2000-2050\end{array}$} & $49.4-61.7$ & $42.4-80.4$ & $\begin{array}{l}\text { Fultz and } \\
\text { Ruck, } \\
2001: 22\end{array}$ \\
\hline \multicolumn{3}{|c|}{$\begin{array}{l}\text { Coverage } \\
\text { pensioners as \% of workers } \\
\text { before } 1992\end{array}$} & $\sim 30 \%$ & $\sim 30 \%$ & $\begin{array}{l}\text { Fultz and } \\
\text { Ruck, } \\
\text { 2001: } 8\end{array}$ \\
\hline
\end{tabular}

